TECHNICAL INFORMATION ON BUILDING MATERIALS

TIBM - 46

FOR USE IN THE DESIGN OF ION-COST HOUSING

\author{
$* * * * * *$ \\ THE NATIONAI BUREAU OF STANDARDS \\ UNITED STATES DEPARTMENT OF COMMERCE \\ TASHINGTOH, D. C.
}

\title{
Kay 5,1937
}

\section{VOIATIIE PAITT AND VARIISH WHINNERS ${ }^{1}$}

This is chiefly a digest of scctions of applicable Federal Snecification ${ }^{2}$ and of the follcring publications of the Natinnal Bureau of Standards dealing with turpentine, aubstitutes for turpentine, composite vehicles, and less important volatile thinnors.

Circular Nn. C69, "Paint and Varnish", (November 17, 1917):3

Technologic Faper No. T274, "Uso of United States Government Specification Paints an i Paint Matcrials", (December 15, 1924), "by P. H. Talker and $\mathbf{E}$. F. Hickson.

\section{Turoentine}

Production and Types: Turpentine, a valuable and widely used volatile thinner for ill paints and most oil-resin varnishes, is produced (a) by distillation of resin from the pine-tree yielding "gum spirits of tur= contine"l, (b) by either steam distillation or destrustive distillation of the pino Food, ylelding "wood turpentine", (c) in the form of sulohate Wond turpentine, a by-product of the paper pulp industry.

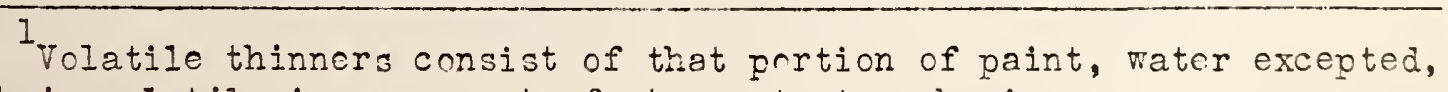
which is vilatils in a current of steam at atmospheric pressure.

${ }^{2}$ Specificatiors alcpted by the Federal Specifications Executive Committee and aporoved by the Director of Frocurcment, Treasury Department, for use of all departments and establishments of the Government. cooics of Fedcral Specifications mentioned in this digest may he obtained from the Superinterdent of Documents, Washington, D. C. (Frice 5 conts)

${ }^{3}$ Out of print and not arajlable by purchase, but may be censulted in envermact sopositery lihrarien.

4 Available fram the Superintendent of Documents, Washsugton, D. C. (Price 10 cents) 
Praperties and Use: Turpentine has excellent "flatting" and good solvent properties. It has excellent penetrating qualities, cvaporates in a satisfactory manner, and is the best solvent for oils, etc., occurring in wcods. Therefore, it should be used in priming coats on nev wcod. There is no objection to using it in all subsequent coats. When paints containing varnish require additional vclatile thinner, it is safest to use turpentine.

Federal Soecifications: - See LLL-T-79la, "Turpentine; (For) Paint, Type I", civering what is known as gum spirits of turpentine, steam-distilled rood turpentine, and sulphate Wrod turpentine; and ILL-T-792, "Turpentine; (For) Paint, Tyoe II", covering what is known as destructively distilled wood turpentine.

-.. There is practically:no difference in evaporation of the two types. However; there is evidence that wod turpentine in certain cases is a somewhat better solvent than gum spirits. Differences in solvent power are imm material. In thinning oil paints, but in the manufacture of certain varnishes they are imoortant. Turpentine has proved to be very helpful in improving the brushing properties of some of the new sinthetic resin varnishes and enamels. In specifying wood turpentine, it is advisable to agree upon a standard samole for cdor.

\section{Turpentine Substitutes}

Substitutes for turpentine are usually prepared from suitable fractions of petroleums. They vary grcatly in specific gravity, flash point, solvent pewer, etc. Therefore, selection must be basel on requirements. Generally sceaking, th $3 y$ must be almost completely volatilized during the drying process and possess suitable solvent power, causing no precipitation of "gum" or polymerized oil in the pairt or varnish.

Petroleum Spirits (Mineral Spirits): Although different fractions frcm the same petroleum vary greatly in solvent power and while there is little evidence to show what, if any, effect the nature of crude petroleum has on the solvent power of mineral spirits made from it, substitutes prepared frcm an asphaltic base Detroleum (Texas) are believed to have better solvent powers than those prepared from a paraffin basc petroleum (Pennsylvania).

Mineral spirits is not as good a solvent as turpentine, but can be used in many cases. The only marked difference between products containing a oetroieum distillate, possessing proper vclatilization and salvent power, and those contining turpertine, is found in the flowing or spreading properties. The influence of the thinner on drying, and the nature of dric 1 film have never been satisfactnrily determined.

The recently developed hydrogenated naphthas have proved to be valuable in utilizing synthetic resins. The se naphthas are much better sclvents than the ordinary mineral spirits.

Federal Specification: See TT-T-291, "Thinner; Paint, Volatile Mineral Spirits" covering that grade of petroleum distillate, knom as mineral spirits or petroleum apirits for use in paint, which evaoorates in a manner 
similar to turpentine. In thinning varnishes with mineral spirits it is, necessary to make sure that the particular varnish being used will mix readily with ther.

Solvent Naphtha (Coal-Tar Naphtha): The distillate of light oil from coaltar, boiling principally between $130^{\circ} \mathrm{C}$ and $160^{\circ} \mathrm{C}$, is a good solvent. It is extensively used, especially in bituminous paints and four-hour type varnishes and enamels, to dissolve synthetic resins. to increase the solvent power of petroleum naphthas, and to keep in solution highly blown or kettled oils. Solvent naphtha is sometimes called $160^{\circ}$ benzol.

\section{Composite Vehicle}

Federal Specification: See Tr-T-271, "Thinner; Paint, (FCr) Semipaste Paints", covering one grade of a composite vehicle which contains in one liquid, drying oil, drier, and volatile thinner intended for use in cheaper paints than straight linseed oil paints. It is used fer single-coat wrrk, generally in repainting jobs, and for semipaste paints when the use of straight linseed oil is not justified. Although paints made with this composite vehicle are inferior to straight linseed oil paints, they frequently give good service.

\section{Iess Important Volatile Thinners}

Benzene (benzol), trluene (teiuol), and xylene (xylol), definite compounds of lower boiling points than solvent naphtha, also derived from the light oil of coal-tar, are sometimes used as volatile thinners. Benzene and toluene are used as volatile thinners particularly in cellulose ester lacquers.

Grain, denatured, and wood alcohol are used principally in shellac varnishes; amyl acetate, amyl alcohol; butyl acetate, and butyl alcohol in nitrc-cellulose lacquers.

I

Such preparations are sometimes called "Thinning Mixtures for Paint", and are also offered under a varjety of trade names, such as "Japan Oil", "Paint Oil", "Linseed Oil Substitute", etc. The term "Iinseed Oil Substitute" should not be used for composite venicle, for while such materials may have decided merit, they are not substitutes for linseed oil. 